\title{
An Evaluation Model for Measuring the Usability of Mobile Office Applications through User Interface Design Metrics
}

\author{
MARIAM NOSHEEN*, ZAHWA SAYED*, MUHAMMAD SAAD MALIK**, AND \\ MUHAMMAD ABUZAR FAHIEM*
}

RECEIVED ON 10.05.2018 ACCEPTED ON 17.08.2018

\begin{abstract}
Usage of mobile devices and particularly smart phones has seen an enormous hike due to the advancement of mobile phone technology in recent times. People of different age groups, one way or the other, are now connected to different mobile phone applications, such as, Social Networking, Chatting, VoIP(Voice Over Internet Protocol) applications, Gaming etc. This rapid advancement has made it necessary for user interface designers of mobile applications to design user friendly interfaces for their applications, so that users can interact and use those applications with ease irrespective of their location. Usability plays a vital role for measuring the usefulness of such applications. After examining different experimental studies on usability assessment techniques imparted by various research workers, it has been determined that there is still a great deal of requirement where application designers have to guarantee more adept and improved usability of offline mobile applications, such as, Conversion Apps, offline encyclopedia, Translation apps, business use applications (office applications) etc. The primary objective of this study is to render a model for usability metrics of measuring the usability of office applications for smart phones. The effectiveness, usefulness and reliability of the proposed model is measured through two office applications named Office Suite Pro7 for Android and Office 365 for Windows 8 touch screen Smartphone.The results of usability testing and t-test show the significance of the proposed approach. The model in this study will enable the application designers to guarantee a more adept and enhanced usability of office applications for smart phones during the designing stage.
\end{abstract}

Key Words: Usability, Usability Evaluation, Office Applications, Usability Testing, Smart Phones.

\section{INTRODUCTION}

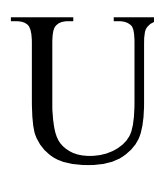

sability has always been a significant element

that should be conceived for designing and developing any kind of application or product, particularly mobile apps [1-2]. With reference to ISO 9241-
111998, usability can be outlined as: "The extent to which a product can be used by assigned users to accomplish determined objectives with effectiveness, efficiency and contentment in an intended context of use" (ISO FDIS 9241-210).

Authors E-Mail: (m_sufyan2000@yahoo.com, zahwa_khushi@hotmail.com, saad.missen@iub.edu.pk, itisab@gmail.com) * Department of Computer Science, Lahore College for Women University, Lahore, Pakistan.

** Department of Computer Science \& Information Technology, The Islamia University of Bahawalpur, Bahawalpur, Pakistan.

This is an open access article published by Mehran University Research Journal of Engineering and Technology, Jamshoro under the CC by 4.0 International License. 
Today, more and more users are being associated with different mobile apps, either online or offline, to make their daily life easier [3]. With reference to the statistics exhibited in [4], approximately 100 million users use office apps on their mobile phones for business and office work every day [5]. After interacting with these devices, users confront numerous issues, such as smaller screen size, navigation, input techniques, personalization issues and many more related to the advent of technology [6-8]. To get the better of such issues, the proper evaluation of usability on the basis of metrics for such devices is needed [2,9-14].

Numerous studies have been conducted where the researchers have adopted and proposed a generic model, framework or technique for evaluating the usability of different kinds of mobile apps or systems (such as haptic systems) [15] and different online mobile apps (Hussain $[10,16]$ that are already in use by number of users (already released) [9-10,17-19].

After analyzing these studies, it has been observed that majority of these models are restricted to the specific usability factors and cannot capture the specific usability problems associated with such applications. Moreover, a limited work is found for such applications in which specific features are measured and over all consolidated usability measurement is ignored. These limitations open the new usability perspectives for designing usability metrics model of mobile office apps.

The proposed model has a capacity to fulfill, not only user needs while using office applications but it also provides an ease while they interact with such applications.

The remainder of this paper is devised as follows: Section 2 provides relevant studies on usability, mobile phones and office apps. Section 3 talks about the suggested model along with its detailed description. Section 4, provides the research methodology. Section 5 describes the outcomes of the study and the last Section 6 addresses the conclusion and future prospects of the study.

\section{LITERATURE REVIEW}

Nowadays, as speedy development could be ascertained in media and applied science, an immense amount of incursion could be ascertained globally in the exercise of mobile phones as depicted in [3-4]. As a consequence of this monumental development, several people dwelling to various age brackets are being associated with mobile phones (either characteristic phones or smart phones) and its different apps [20]. Mobile apps can be outlined as those application systems which operate on mobile devices [21]. With the fast and developing requirements of mobile phones and its apps, several users are being engaged with different kinds of apps like financial apps, marketing and advertising apps, education apps etc. $[20,22]$

As a consequence of this speedy development, several research workers are being appealed for drawing out their researches addressing different usability skills pertaining mobile apps as summed up in Table 1.

\section{$2.1 \quad$ Usability}

Usability has always been a significant element that should be conceived for designing and developing any kind of application or product particularly mobile apps [1]. According to International Standard Organization (ISO 9241-11, 1998), usability of any product can be achieved through effectiveness, efficiency and satisfaction in an intended context of use. 
With the passage of time, several researchers have suggested different usability frameworks and standards comprising of various usability properties for multiple applications [1,13]. Walji et. al. [23] in his research, found that considering usability as an important element in designing any application provide benefits to both users as well the designers. From literature analysis it was found that user get frustrated, bored, disappointed if they did not feel ease to operate the software according to their needs [21,23,31]. Moreover, it was also found that majority of the usability studies are limited in covering the usability problems and did not cover the specific problem areas as detailed in Table 1.

TABLE 1. REVIEW OF USABILITY EVALUATION STUDIES FOR MOBILE APPLICATIONS

\begin{tabular}{|c|c|c|c|c|c|c|c|c|c|}
\hline Author & $\begin{array}{l}\text { Nature of } \\
\text { Research }\end{array}$ & $\begin{array}{l}\text { Proposed } \\
\text { Approach } \\
\end{array}$ & $\begin{array}{c}\text { Usability } \\
\text { Characteristics } \\
\end{array}$ & $\begin{array}{c}\text { Metrics } \\
\text { Type }\end{array}$ & $\begin{array}{c}\text { User } \\
\text { Profile } \\
\end{array}$ & $\begin{array}{c}\text { Test } \\
\text { Environment } \\
\end{array}$ & Equipment & \begin{tabular}{c|} 
Usability Evaluation \\
Technique \\
\end{tabular} & Validation \\
\hline $\begin{array}{c}\text { Hussain et. al. } \\
{[10]}\end{array}$ & Conceptual Model & Hierarchical & $\begin{array}{c}\text { Efficiency, } \\
\text { Effectiveness, } \\
\text { Satisfaction }\end{array}$ & Both & - & 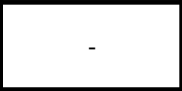 & - & 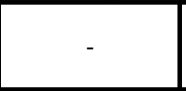 & No \\
\hline $\begin{array}{c}\text { Khan et. al. } \\
\text { [15] }\end{array}$ & Framework & Hierarchical & \begin{tabular}{|c|} 
Efficiency, \\
Effectiveness, \\
Satisfaction, \\
Learnability, Safety
\end{tabular} & Both & - & - & - & - & No \\
\hline $\begin{array}{l}\text { Gafni et. al. } \\
\text { [19] }\end{array}$ & Model & - & $\begin{array}{c}\text { Understandability, } \\
\text { Learnability, } \\
\text { Operability, } \\
\text { Attractiveness }\end{array}$ & Objective & - & Laboratory Based & $\begin{array}{l}\text { PDA's, Phone, } \\
\text { Desktop }\end{array}$ & Usability Testing & Yes \\
\hline $\begin{array}{c}\text { Walji et. al. } \\
\text { [23] }\end{array}$ & $\begin{array}{l}\text { Evaluation } \\
\text { Study }\end{array}$ & - & $\begin{array}{l}\text { Effectiveness, } \\
\text { Efficiency, } \\
\text { Satisfaction }\end{array}$ & Objective & Expert & Laboratory Based & Tablets & $\begin{array}{c}\text { Usability Testing, } \\
\text { Interviews, } \\
\text { Observations }\end{array}$ & Yes \\
\hline $\begin{array}{c}\text { Hussain et. al. } \\
{[24]}\end{array}$ & $\begin{array}{l}\text { Comparative } \\
\text { Analysis }\end{array}$ & Hierarchical & \begin{tabular}{|c|} 
User \\
Satisfaction(Overal \\
Reactions, Screen, \\
Terminology And \\
Information, \\
Learning, \\
Application \\
Capabilities, \\
General \\
Impressions, \\
Mobile Device) \\
\end{tabular} & Subjective & Both & Laboratory Based & Smart Phone & $\begin{array}{l}\text { Questionnaires, } \\
\text { Interviews }\end{array}$ & Yes \\
\hline $\begin{array}{l}\text { Giannopoulos et. } \\
\text { al. [25] }\end{array}$ & Method & - & \begin{tabular}{c|} 
Effectiveness, \\
Efficiency
\end{tabular} & Objective & Expert & Laboratory Based & Smart Phone & $\begin{array}{l}\text { Usability Testing. } \\
\text { Video Recording }\end{array}$ & Yes \\
\hline $\begin{array}{l}\text { Shivade et al. } \\
{[26]}\end{array}$ & $\begin{array}{l}\text { Usability Tool } \\
\text { Construction }\end{array}$ & - & \begin{tabular}{|c|} 
Effectiveness, \\
Efficiency, \\
Attractiveness, \\
Productivity, \\
Response Time, \\
Understand ability
\end{tabular} & Objective & - & - & Smart Phone & $\begin{array}{l}\text { Questionnaire:, } \\
\text { logging }\end{array}$ & Yes \\
\hline $\begin{array}{c}\text { Faliagka et. al. } \\
{[27]}\end{array}$ & $\begin{array}{l}\text { Evaluation } \\
\text { Study }\end{array}$ & - & \begin{tabular}{|c|} 
Visibility, \\
Feedback, \\
Consistency, Non- \\
destructive \\
Operations, \\
Discoverability, \\
Scalability, \\
Reliability \\
\end{tabular} & Subjective & Novice & Laboratory Based & Smart Phone & Usability Testing & Yes \\
\hline $\begin{array}{l}\text { Hoehle et. al. } \\
\text { [28] }\end{array}$ & $\begin{array}{l}\text { Usability Tool } \\
\text { Construction }\end{array}$ & Hierarchical & \begin{tabular}{|} 
Aesthetic graphics, \\
Color, Control \\
obviousness, Entry \\
point, Fingertip- \\
size controls, Font, \\
Gestalt, Hierarchy, \\
Subtle animation, \\
Transition \\
\end{tabular} & - & - & - & Smart Phone & Survey, Testing & Yes \\
\hline $\begin{array}{c}\text { Ventayen et. al. } \\
\text { [29] }\end{array}$ & Usability Evaluation & - & $\begin{array}{c}\text { Understandability, } \\
\text { Operability, } \\
\text { Satisfaction, } \\
\text { Learnability, } \\
\text { Attractiveness } \\
\end{array}$ & Both & Expert & - & Smart Phones & Questionnaires & Yes \\
\hline $\begin{array}{c}\text { Hussain et. al. } \\
\text { [30] }\end{array}$ & Usability Evaluation & - & $\begin{array}{l}\text { Effectiveness, } \\
\text { Efficiency, } \\
\text { Satisfaction }\end{array}$ & Both & Both & Laboratory Based & Smart Phone & Usability Testing & No \\
\hline
\end{tabular}

Mehran University Research Journal of Engineering \& Technology, Volume 38, No. 3, July, 2019 [p-ISSN: 0254-7821, e-ISSN: 2413-7219] 
According to [10], it is important to consider usability as an important element when designing mobile applications. While designing mobile applications, several restrictions are imposed like small screen size, navigational problem, input mechanisms, mobile personalization problems and new technological problems [7-8]. Keeping these problems in mind, it has become essential for designers to pay serious attention when evaluating usability of various applications, especially mobile applications.

\subsection{Usability Evaluation for Mobile Applications}

Evaluating usability of mobile application has always been a critical issue [19-21]. With the passage of time, several researchers have suggested different usability models related to mobile applications [1-2,13]. A number of such models for usability measurement are available for reference in Table 1. In Table 1 it is found that majority of the previous usability studies focused on individual usability evaluation or tool development of any specific application. Majority of these usability studies targeting either objective or subjective metrics individually. The testing procedure is also limited to novice or expert users. Moreover, majority models are conceptual and not validated for any case study. These models cover only one or two usability factors with limited dataset. In literature, the researchers also pointed out different areas which needed to be addressed and improved by the usability experts for mobile applications.

\subsection{Usability for Mobile Office Applications}

From Table 1 it is found that there is a knowledge gap related to the improvement in usability evaluation models for mobile applications. With the wide spread usage of touch screen smartphones, users are demanding more usable and interactive applications, especially when it comes to business and office applications, like mobile office apps $[4,20]$. Various studies have been conducted to determine usability of office products like spread sheet, word processing for personal computers but a limited work has been found for mobile devices.

Venkatesh et. al. [32], in his research pointed out four major influencing factors (mobile devices screen size, resolution, input style and power consumption) which affect the mobile user experience during interaction. He suggested that improvements in these factors at the application level will enhance the user satisfaction level for such applications.

Moumane et. al. [6] presented two software quality evaluation frameworks for measuring the quality of mobile softwares. These frameworks are based on ISO 9126 standard and address mobile environmental issues like low bandwidth, limited storage capacities and limited user interfaces. They proposed that the frameworks need to be refined in terms of usability and maintainability.

Guirguis et. al. [33] have provided a smart model which facilitates the mobile user to access the web contents easily and smartly. The subjective metrics in terms of user satisfaction for the proposed model is collected from desktop and mobile devices. The authors suggested the need of more objective metrics need to be explored with high data set of participants.

Wogalter et. al. [34] in their research focus on the usability problems in word processing PC based applications. They focus on the feature characteristics of these applications. At the end they stress the importance of usability and highlighted that poor usability would increase user attention, disturbance levels, consume more time and causes low productive word documents. 
Hussain et. al. [16] have provided a subjective usability metrics using GQM (Goal Question Metrics) approach for web based applications. They conducted interview session of 30 participants with mix gender and experience levels. The basic purpose of their research was to understand the device influence on mobile applications usability. For that they use two mobile phone applications (OSX iPhone and an O2 applications) running on two different platforms. At the end they suggested that mobile devices have a strong influence on user satisfaction. They also stress to incorporate objective usability metrics so that the understandability of user satisfaction can be examined more comprehensively. Few authors like Veera Chaintapalli et. al. [35], Bota et. al. [36], and Attar [37] explorer usability through objective metrics. They explore usability with limited number of participants for specific application type (e.g. Spread sheets). Those researchers cover limited usability factors.

The literature review breakdown presented in Table 2 gives summary of research contributions towards usability metrics framework and major attributes of office applications.

\section{PROPOSEDEVALUATIONMODELFOR MOBILE OFFICE APPLICATION}

Based on the review of literature, it is evident that some factors tend to influence the adoption and aid to improve usability of mobile office applications. Four factors are identified from Tables 1-2 which are categorized as simplicity, efficiency, effectiveness and satisfaction. Some new factors like attractiveness, attitude and memorability have also been segregated with existing mobile usability factors keeping in mind the limitations found in Tables 12. Proposed conceptual model is depicted in Fig. 1. In this section, suggested usability metrics model has been discussed. The suggested model is shown in Fig. 1. The usability model suggested in this research work is designed on the basis of mGQM (mobile Goal Question Metric) framework which hierarchically constitutes three steps described in $[10,24]$. The suggested usability metrics model comprises of following three layers.

\subsection{Layer-1: Defining Content Based Usability Attributes for Smart Phones}

In the first Layer, a new property namely "simplicity" has been imparted $[10,24]$. Reason behind adding this element is that after analyzing smart phone's guidelines published by [39], it has been observed that user interface should be developed simple in an attempt to enable users to interact comfortably with the application or system. As proposed by [11] it is imperative to develop simple user interfaces for enabling users to interact comfortably with mobile apps particularly with business and social networking applications.

So for such reasons, "Simplicity" property has been added in a usability metrics model along with other three properties outlined by $[10,24]$. There are some research workers who have assessed online office apps [12] and Microsoft Word apps being used on personal computer [17]. In this research paper, main focus is on assessing usability of mobile office apps. To assess these apps, content based usability properties have been distinguished generally pertaining to mobile office apps. The identified properties are Simplicity, Efficiency, Effectiveness and Satisfaction.

Simplicity: The first category of usability factors is simplicity. Simplicity is measured in terms of user's level of ease for performing given tasks like editing, insertion, formatting etc. and learning how to recover from mistakes committed while performing tasks. Prior researches 
emphasize that simplicity sub factors like Easiness, Learnability and Visibility are considered important determinant for evaluating usability of mobile office applications [6,9-12,18]. Simplicity is evaluated by metrics: level to which users find it easy: to edit data, insert table, picture, chart and shapes, to recover from errors/mistakes while performing tasks and to timely discover how to perform a specific task $[11,16]$.

TABLE 2. USABILITY METRICS FRAMEWORKS/MODELS FOR MOBILE OFFICE APPLICATIONS

\begin{tabular}{|c|c|c|c|c|c|c|c|c|}
\hline Author & $\begin{array}{c}\text { Usability } \\
\text { Characteristics }\end{array}$ & Metrics & $\begin{array}{l}\text { Measurement } \\
\text { Technique }\end{array}$ & $\begin{array}{l}\text { Usability } \\
\text { Evaluation } \\
\text { Technique }\end{array}$ & Application & Device & OS & Metrics Type \\
\hline \multirow{5}{*}{$\begin{array}{c}\text { Khan et. al. } \\
\text { [12] }\end{array}$} & Effectiveness & $\begin{array}{c}\text { Accuracy and completeness of specific } \\
\text { goals }\end{array}$ & \multirow{5}{*}{ Mean } & \multirow{5}{*}{$\begin{array}{l}\text { Questionnaire, } \\
\text { Think Aloud, } \\
\text { Usability } \\
\text { Testing }\end{array}$} & \multirow{5}{*}{$\begin{array}{l}\text { Web Office } \\
\text { Application }\end{array}$} & \multirow{5}{*}{$\mathrm{PC}$} & \multirow{5}{*}{$\begin{array}{l}\text { Windows } \\
\text { vista and } \\
\text { windows XP }\end{array}$} & \multirow{5}{*}{ Both } \\
\hline & Efficiency & $\begin{array}{l}\text { Expansion of system resources to get } \\
\text { accurate and completed tasks }\end{array}$ & & & & & & \\
\hline & Satisfaction & Measure the comfort level of user & & & & & & \\
\hline & \begin{tabular}{|l|} 
Learnability \\
\end{tabular} & Measure the positive attitude of user & & & & & & \\
\hline & Utility & $\begin{array}{c}\text { Estimate how easy for the user to use the } \\
\text { system }\end{array}$ & & & & & & \\
\hline $\begin{array}{c}\text { Hussain et. al. } \\
{[16]}\end{array}$ & Satisfaction & $\begin{array}{c}\text { Estimates overall user reactions, } \\
\text { Rate over all Screen } \\
\text { Rate Terminologies and information } \\
\text { Measure the Learnability, } \\
\text { Measure over all application capabilities } \\
\text { Measure general Impressions } \\
\text { Rate over all Mobile Device } \\
\end{array}$ & $\begin{array}{l}\text { Mean, } \\
\text { Standard } \\
\text { Deviation }\end{array}$ & $\begin{array}{l}\text { Questionnair- } \\
\text { e(QUIS) and } \\
\text { Interview }\end{array}$ & $\begin{array}{c}\text { Web } \\
\text { Application(- } \\
\text { Goggle Doc) }\end{array}$ & Smart Phone & osX, O2 & Subjective \\
\hline $\begin{array}{l}\text { Wogalter et. } \\
\text { al. [34] }\end{array}$ & Features & $\begin{array}{c}\text { Check importance of Tool bars text only } \\
\text { Check importance of Tool bars Icon only } \\
\text { Check importance of toll bars text and } \\
\text { icons } \\
\text { Check importance of auto features } \\
\text { Rate importance of graphic, picture, } \\
\text { formatting options Rate help feature. } \\
\end{array}$ & $\begin{array}{l}\text { Mean, } \\
\text { Standard } \\
\text { Deviation }\end{array}$ & Questionnaire & $\begin{array}{c}\text { Word } \\
\text { processing } \\
\text { Application }\end{array}$ & $\mathrm{PC}$ & - & Objective \\
\hline \multirow{9}{*}{$\begin{array}{c}\text { Veera et. al. } \\
{[35]}\end{array}$} & Visibility & $\begin{array}{c}\text { Measure the display size of spread sheet, } \\
\text { Measure the glance ability of spread sheet } \\
\text { Measure the zoom ability of data } \\
\text { Measure the overall look and feel of speed } \\
\text { sheet }\end{array}$ & & \multirow{9}{*}{$\begin{array}{c}\text { Survey, } \\
\text { Questionnaire }\end{array}$} & \multirow{9}{*}{$\begin{array}{l}\text { Spread Sheet } \\
\text { Application }\end{array}$} & \multirow{9}{*}{ Smart Phone } & \multirow{9}{*}{$\begin{array}{l}\text { Android and } \\
\text { iOS }\end{array}$} & \multirow{9}{*}{ Objective } \\
\hline & Navigation & \begin{tabular}{|c|}
$\begin{array}{c}\text { Measure the user position in the speed } \\
\text { sheet }\end{array}$ \\
\end{tabular} & & & & & & \\
\hline & Scrolling & $\begin{array}{l}\text { Measure the movability of test, screen in } \\
\text { different directions }\end{array}$ & & & & & & \\
\hline & Feedback & $\begin{array}{c}\text { Measure the system clear and easy } \\
\text { responses when user needs help. }\end{array}$ & & & & & & \\
\hline & Interaction & $\begin{array}{l}\text { Measure the degree of interaction of user } \\
\text { and the system }\end{array}$ & & & & & & \\
\hline & Satisfaction, & $\begin{array}{c}\text { Measure the degree to which the product } \\
\text { meets the customer expectations }\end{array}$ & & & & & & \\
\hline & Simplicity & Measure the alternative shortcuts & & & & & & \\
\hline & Convenience & $\begin{array}{c}\text { Measure the understandability of the user } \\
\text { for different tasks }\end{array}$ & & & & & & \\
\hline & Searching & \begin{tabular}{|c|}
$\begin{array}{c}\text { Measure the user effort energy and } \\
\text { resources to complete the tasks }\end{array}$ \\
\end{tabular} & & & & & & \\
\hline $\begin{array}{l}\text { Bota et. al. } \\
\quad[36]\end{array}$ & Searching & $\begin{array}{l}\text { How the search option is distributed across } \\
\text { multiple queries } \\
\text { How frequently user do use search option } \\
\text { What type of search is done by the user }\end{array}$ & Mean & $\begin{array}{l}\text { Office } \\
\text { instrumentati- } \\
\text { on Logs. }\end{array}$ & $\begin{array}{l}\text { Microsoft } \\
\text { Office }\end{array}$ & $\begin{array}{l}\text { Laptops, } \\
\text { PC's, Smart } \\
\quad \text { Phone }\end{array}$ & Window & Objective \\
\hline \multirow{3}{*}{$\begin{array}{l}\text { Attar et. al. } \\
\text { [37] }\end{array}$} & Satisfaction & $\begin{array}{l}\text { s the users satisfied while utilizing the Open } \\
\text { source software }\end{array}$ & \multirow{3}{*}{ Mean } & \multirow{3}{*}{ Survey } & \multirow{3}{*}{$\begin{array}{c}\text { Open source } \\
\text { office } \\
\text { Application }\end{array}$} & \multirow{3}{*}{ Laptop, PC's } & \multirow{3}{*}{ Linux } & \multirow{3}{*}{ Objective } \\
\hline & Effectiveness & $\begin{array}{c}\text { How the user effectively(error free, } \\
\text { economically, cost, compatibility) utilize the } \\
\text { system }\end{array}$ & & & & & & \\
\hline & Acceptability & $\begin{array}{c}\begin{array}{c}\text { Measure the easiness to download and } \\
\text { Operate the system }\end{array} \\
\end{array}$ & & & & & & \\
\hline \multirow{2}{*}{$\begin{array}{l}\text { Castellucci et. } \\
\text { al. [38] }\end{array}$} & $\begin{array}{l}\text { Text entry } \\
\text { Speed } \\
\end{array}$ & $\begin{array}{l}\text { Estimate the text speed in words-per- } \\
\text { minute (wpm). }\end{array}$ & \multirow{2}{*}{$\begin{array}{l}\text { Mean and } \\
\text { standard } \\
\text { deviation }\end{array}$} & \multirow{2}{*}{$\begin{array}{l}\text { Testing, } \\
\text { event logs }\end{array}$} & \multirow{2}{*}{ Text Entry } & \multirow{2}{*}{ Smart Phone } & \multirow{2}{*}{ Android } & \multirow{2}{*}{ Objective } \\
\hline & Accuracy & $\begin{array}{c}\text { Estimates total (corrected and uncorrected) } \\
\text { errors rate. }\end{array}$ & & & & & & \\
\hline
\end{tabular}

Mehran University Research Journal of Engineering \& Technology, Volume 38, No. 3, July, 2019 [p-ISSN: 0254-7821, e-ISSN: 2413-7219] 
Efficiency: The second category of usability factors incorporates user's way of performing tasks in a given time constraint. Prior research asserted that efficiency sub factors like time behavior, features are the most important determinants of the measuring usability of mobile office applications [6,9-10,16]. Efficiency is evaluated by metrics: The capacity of a system (application) to enable users to ably interact with the application's supported characteristics and complete specific assignments with precise and successful outcomes within the anticipated period of time [9,11-12,40].
Effectiveness: The third category of usability factors is effectiveness. Effectiveness is measured in terms of user's ability of performing tasks in a simple way, completely and accurately. Former research emphasizes that effectiveness sub factors like accuracy, completeness and Memorability are important determinants for evaluating usability of mobile office applications [9-12,16,18]. Effectiveness is measured by metrics: Application's capacity to enable users to accomplish intended assignments precisely and completely, the extent to which the application is made easy for users to interact and

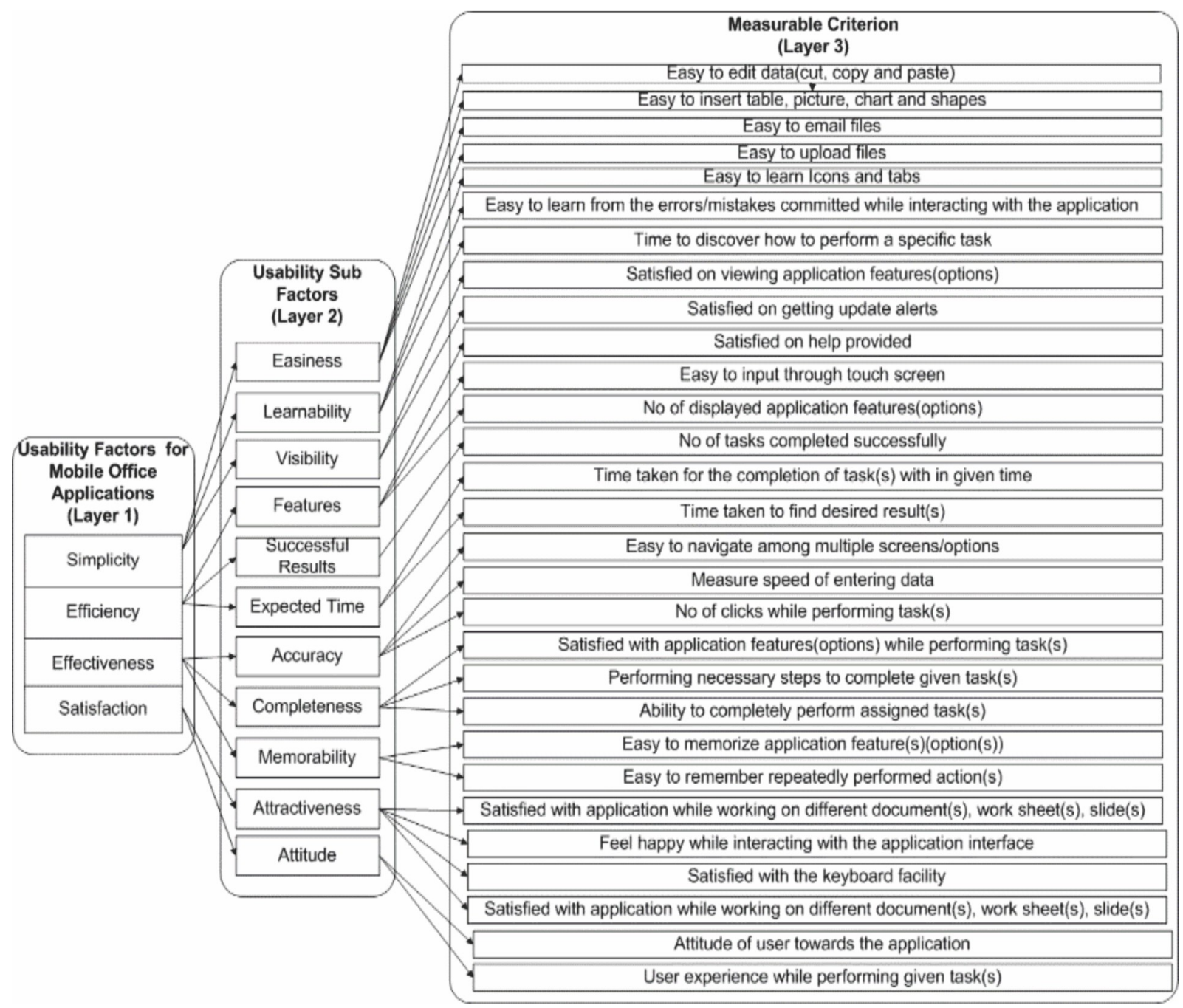

FIG. 1. PROPOSED EVALUATION MODEL FOR MEASURING THE USABILITY OF MOBILE OFFICE APPLICATIONS USER INTERFACES

Mehran University Research Journal of Engineering \& Technology, Volume 38, No. 3, July, 2019 [p-ISSN: 0254-7821, e-ISSN: 2413-7219] 
learnable from in terms of error actions executed on the user interface $[6,9-12,16,40]$. Various editions of the same application and learn all the characteristics supported by an application and actions executed on the user interface.

Satisfaction: The fourth category of usability factor is satisfaction. Satisfaction is considered major determinant for evaluating usability of mobile office applications. As seen from previous research, user's attitude, attractiveness are considered major sub factors for evaluating usability and user experience of mobile applications $[6,11-12,18,40]$. Satisfaction is measured in terms of metrics: user's attraction towards the application's user interface and its supported choices, positive attitude while using the application, comfort level with the screen preferences and keyboard facility and are delighted with the display quality and resolution as well as with the customization facilities [10-12, 14,16,40].

\subsection{Layer-2: Defining Sub Factors for the Defined Attributes}

In this layer, sub components for the content based usability properties distinguished in previous layer regarding mobile office apps are outlined. These sub components are distinguished after studying different studies on usability assessment of various kinds of systems and application like Mobile-Wireless Information systems [19], online apps [12,41] and mobile apps $[10,24,31]$.

\subsection{Layer-3: Developing Measurable Criterion (Metrics) for Defined Sub Factors}

Once the sub components have been outlined in layer 3 , in this step, the standard (systems of measurement) for assessing these sub components are designed by critiquing the systems of measurement outlined in $\mathrm{mGQM}$ framework [10,24].
Except critiquing mGQM framework, different studies associated to usability metrics model and frameworks [9] for assessing various kinds of systems and application like Mobile-Wireless Information Systems [19], Webbased apps [40], Mobile apps [10,34] are also reviewed. After reviewing all these studies, standard (systems of measurement) for assessing usability of mobile office apps is finalized. Once the standard is finalized, the questionnaire is developed keeping in mind the standard finalized for assessing mobile office apps. This questionnaire is developed on the basis of queries developed by [11]. Principal objective of designing this questionnaire is to assess the usability of mobile office apps by knowing user's comments and suggestions against every question developed on the basis standard outlined for such apps. The suggested usability metrics model for mobile office application is shown in Fig. 1.

\section{RESEARCH METHODOLOGY}

This section describes the material and methods used for the development and validation of the proposed model. For designing the proposed model we empirically review the previous researches of usability and mobile applications especially mobile office applications. Majority authors presented their models or frameworks in a hierarchal way [42-43] and structured their models by using mGQM approach $[24,43]$. For the construction of our proposed model we also adopted $\mathrm{GGQM}$ in which we use usability factors as usability goals and measurement criteria as metrics. Once the metrics are defined we prepare an instrument based on questions which are using 5 point Likert Scale ranged from 1-5, where 1 means low and 5 means high.

The proposed metrics in Fig. 1 are the combination of both objective and subjective metrics. The objective metrics are task based while the subjective metrics are 
questioner based. The data for objective metrics were gathered from usability testing. For calculating the objective metrics different weights were assigned to individual metrics e.g. Table 3. The subjective metrics were collected from posttest questioner (instrument) which was based on 5 point Likert scale. The data collected from the objective and subjective metrics were used to calculate the mean values of individual usability sub factor (see Equation (1)). These mean values were then used to compute the mean percentage of major usability factors see Equation (2).

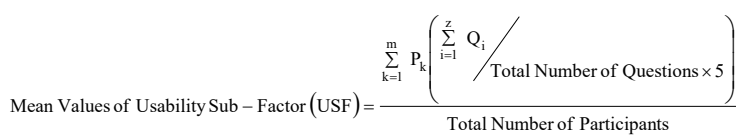

Mean Percentage of Major Usability Factor $(\mathrm{USF})=\frac{\sum_{l=1}^{\mathrm{n}} \mathrm{USF}_{1}}{\mathrm{~N}} \times 100$

where ' $P$ ' means Participants, 'Q' refers to as Question, ' $\mathrm{m}$ ' is total number of participants, ' $\mathrm{z}$ ' refers as the number of questions lie in one usability sub factor and ' $\mathrm{N}$ ' means no. of usability sub factors

To validate the proposed model two case studies are selected for usability testing. The test results and the instrument are validated and analyzed by using the ttesting and Cronbach's Alpha respectively. The flow diagram of the research methodology is given in Fig. 2.

\subsection{Usability Testing}

There are several mobile apps that are installed on different operating system based smart phones. In an attempt to ascertain the suitability of the suggested model on mobile office apps, usability tests were carried out on two diverse platform named Android and Windows 8 , This method was used for assessing the suggested model on two most trendy mobile office apps i.e. Office Suite Pro 7 for android devices and Office 365 for Windows 8 mobile. Using these apps, users can create word documents, PowerPoint presentations and excel spreadsheets and can share them via email or other cloud services like Drop Box, Sugar Sync etc.

During usability test 65 respondents were selected, they were mixed between gender, skill, experience levels and lie between 20-50 year old age.

To execute usability tests, successions of four assignments were designated to selected respondents. Before designating assignments to the respondents, pilot testing was carried out with 2 respondents acquainted with both chosen apps i.e. A1 (Office Suite Pro 7) for android devices and A2 (Office 365) for Windows 8 mobile were selected. While doing jobs on two various devices, Respondents were inquired to Think Aloud. This method was used with the objective of observing down participant's feedback and ideas against each job.

TABLE 3. SAMPLE WEIGHT TABLE FOR OBJECTIVE METRICS FOR APP-1

\begin{tabular}{|c|c|c|c|c|c|c|c|c|c|}
\hline Usability Factor & $\begin{array}{c}\text { Usability Sub } \\
\text { Factor }\end{array}$ & $\begin{array}{c}\text { Measurement } \\
\text { Criterion }\end{array}$ & Tasks & $\begin{array}{c}\text { Measurement } \\
\text { Unit }\end{array}$ & \multicolumn{5}{|c|}{ Groups with Weights } \\
\hline \multirow{2}{*}{ Efficiency } & \multirow{2}{*}{ Expected Time } & \multirow{2}{*}{$\begin{array}{c}\begin{array}{c}\text { Time taken for } \\
\text { the completion of } \\
\text { tasks within given } \\
\text { time }\end{array} \\
\end{array}$} & \multirow{2}{*}{ Task-1 } & \multirow{2}{*}{$\begin{array}{l}\text { Total Time } \\
10 \text { mins }\end{array}$} & $<1 \min$ & $\begin{array}{c}\text { Between } 1 \text { and } \\
3 \text { mins } \\
\end{array}$ & $\begin{array}{l}\text { Between } 4 \\
\text { and } 6 \text { mins } \\
\end{array}$ & $\begin{array}{r}\text { Between } 7 \\
\text { and } 9 \text { mins } \\
\end{array}$ & $\begin{array}{l}>9 \\
\text { mins } \\
\end{array}$ \\
\hline & & & & & 5 & 4 & 3 & 2 & 1 \\
\hline \multirow{2}{*}{ Effectiveness } & \multirow{2}{*}{ Accuracy } & \multirow{2}{*}{$\begin{array}{c}\text { No of clicks } \\
\text { while performing } \\
\text { task(s) }\end{array}$} & \multirow{2}{*}{ Task-1 } & \multirow{2}{*}{$\begin{array}{c}\text { Total no of clicks } \\
\text { (3) }\end{array}$} & $<4$ clicks & 4 click & 5 clicks & 6 clicks & $>6$ clicks \\
\hline & & & & & 5 & 4 & 3 & 2 & 1 \\
\hline $\begin{array}{l}. \\
. \\
.\end{array}$ & $\begin{array}{l}\cdot \\
\cdot \\
.\end{array}$ & $\begin{array}{l}\cdot \\
\dot{ } \\
.\end{array}$ & $\begin{array}{l}\cdot \\
. \\
.\end{array}$ & . & $\begin{array}{l}\cdot \\
. \\
.\end{array}$ & $\begin{array}{l}\cdot \\
\cdot \\
.\end{array}$ & $\begin{array}{l}\cdot \\
. \\
.\end{array}$ & $\begin{array}{l}\cdot \\
\dot{ } \\
.\end{array}$ & $\begin{array}{l}\cdot \\
. \\
.\end{array}$ \\
\hline
\end{tabular}

Mehran University Research Journal of Engineering \& Technology, Volume 38, No. 3, July, 2019 [p-ISSN: 0254-7821, e-ISSN: 2413-7219] 


\section{RESULTS AND DISCUSSION}

In the field of HCI (Human Computer Interaction), the researchers pointed out that design methods, frameworks, and models cannot be qualitatively validated [44]. And this statement can also be applicable for usability models too [45]. In literature, researchers validate their models through following key factors (1) identification of usability problems [42-43], (2) categorization of improvement areas [43] and (3) usefulness [42]. For validating our proposed model we use these factors and validate them by using user-based assessment, statistical techniques and usability engineering methods. This segment delineates the methods that are used for assessing the suggested model, the prerequisite for examination and instruments used for analyzing and assembling of outcomes.
In this research work we use two case studies named as Office Suite Pro 7 and Office 365 for usability testing the cumulative mean based results of the two case studies after usability testing are given in Table 4 . The mean based analysis of the both applications is given in Figs. 3-5.

An independent t-test was carried out to compare both applications. The mean percentage values of usability factors for both applications were used for t-testing. The results show that there is a significant difference in the means of both applications where $\mathrm{t}=0.468$ when $\mathrm{p}=0.05$. The t-test result positively supports the proposed usability goals that mobile office automation applications are aligned with the proposed model and proposed models have a capability to compare and target multiple usability

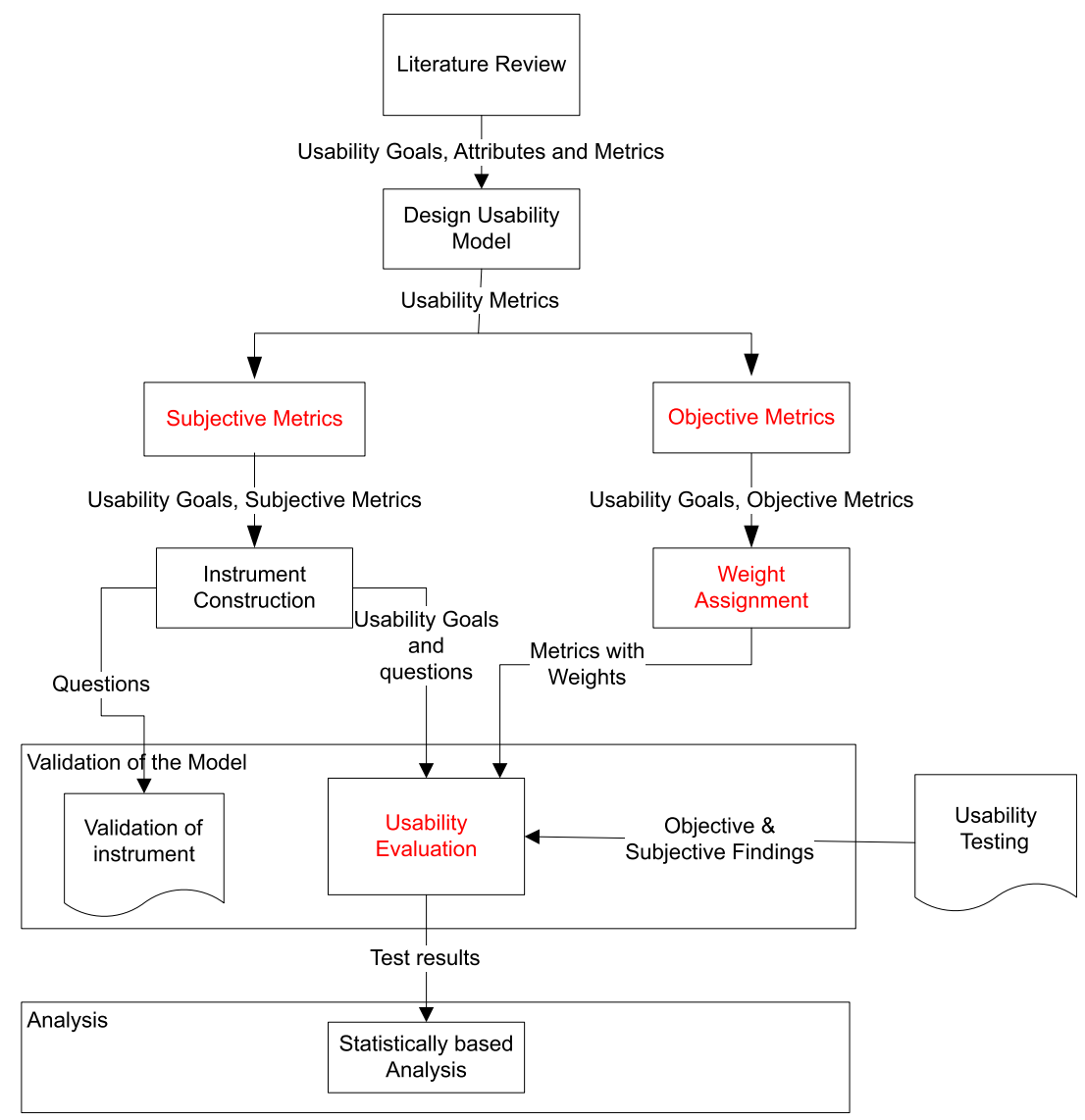

FIG. 2. FLOW OF RESEARCH METHODOLOGY

Mehran University Research Journal of Engineering \& Technology, Volume 38, No. 3, July, 2019 [p-ISSN: 0254-7821, e-ISSN: 2413-7219] 
problems for different nature of applications. Table 4 shows that App1(Office Suite) provides better visibility, learnability and ease to its users as compared to App2(Office 365). The results presented in Table 4 also show that App-2 (Office 365) is more attractive, memorable and offers better features as compared to App-1(Office Suite).During usability testing participants also indicate that App-1 (Office Suit) is easy in editing and formatting functionalities but App-2 (Office365) touch functionality and help facilities are better than the App-1 (Office Suit). It also indicates that the proposed model has an ability to act as a useful tool by providing usability factors for the mobile application designers so that they can test their applications accordingly. For checking the reliability of the instrument we use Cronbach's Alpha techniques for both applications. The results of the applications are 0.36 and 0.31 which indicate that the items in the instrument are reliable.

The overall analysis of the results shows that the proposed model acts as a base for mobile office automation application designers. It is capable of identifying the usability problems for mobile office applications with diverse platforms. It is also useful for comparing different applications and identifies various improvement areas.

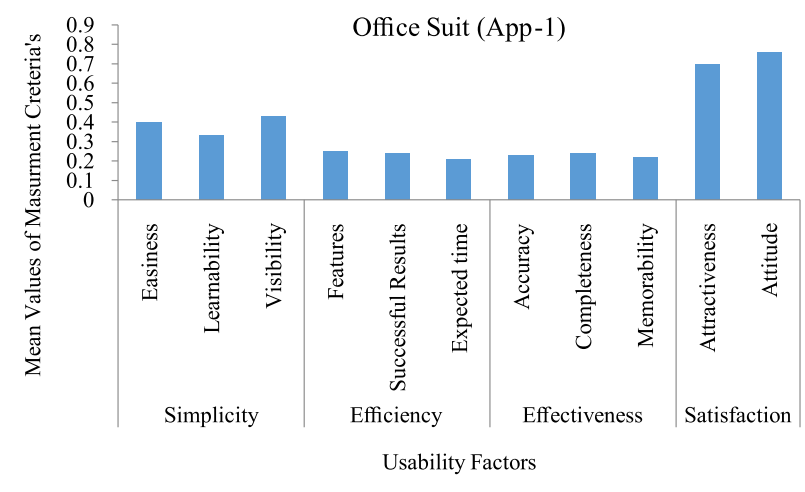

FIG. 3. MEAN BASED ANALYSIS OF USABILITY FACTORS FOR APP-1

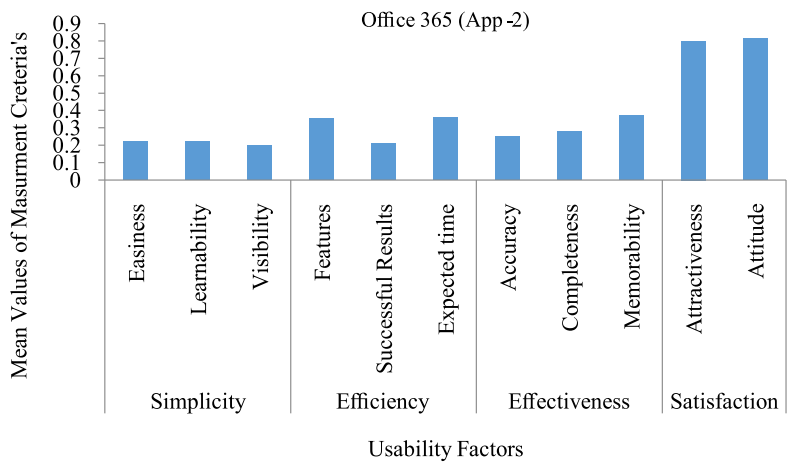

FIG. 4. MEAN BASED ANALYSIS OF USABILITY FACTORS FOR APP-2

TABLE 4. CUMULATIVE RESULTS OF BOTH APPLICATIONS

\begin{tabular}{|c|c|c|c|}
\hline \multirow{3}{*}{ Usability Factors } & Usability Sub Factors & Office Suit (App-1) & Office 365 (App-2) \\
\hline \multirow{3}{*}{ Simplicity } & Easiness & 0.40 & 0.22 \\
\cline { 2 - 4 } & Learnability & 0.33 & 0.22 \\
\cline { 2 - 4 } & Visibility & 0.43 & 0.20 \\
\hline \multirow{3}{*}{ Efficiency } & Features & 0.25 & 0.35 \\
\cline { 2 - 4 } & Successful Results & 0.24 & 0.21 \\
\cline { 2 - 4 } & Expected time & 0.21 & 0.36 \\
\hline \multirow{3}{*}{ Effectiveness } & Accuracy & 0.23 & 0.25 \\
\cline { 2 - 4 } & Completeness & 0.24 & 0.28 \\
\cline { 2 - 4 } & Memorability & 0.22 & 0.37 \\
\hline \multirow{2}{*}{ Satisfaction } & Attractiveness & 0.70 & 0.8 \\
\hline
\end{tabular}

Mehran University Research Journal of Engineering \& Technology, Volume 38, No. 3, July, 2019 [p-ISSN: 0254-7821, e-ISSN: 2413-7219] 


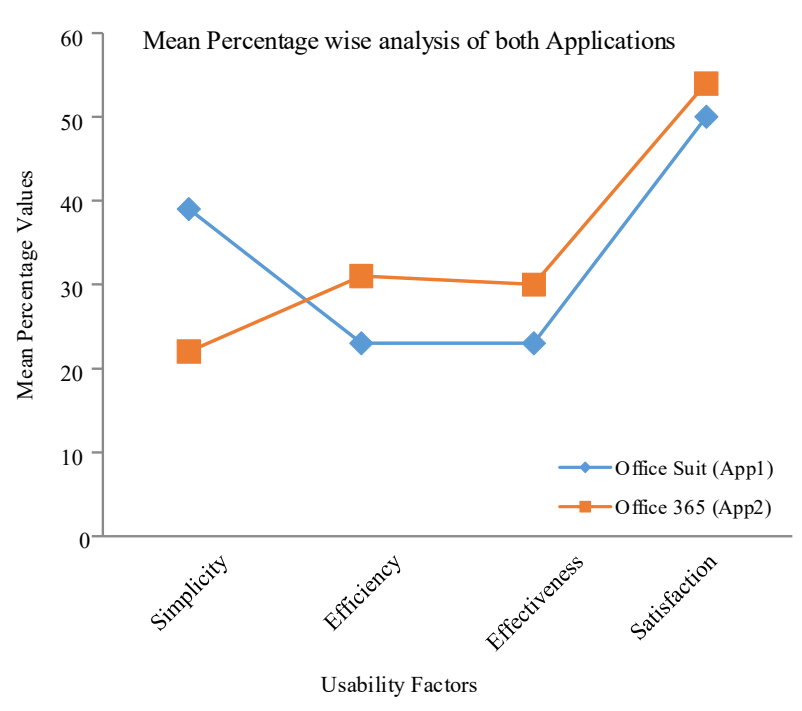

FIG. 5. COMPARATIVE ANALYSIS OF BOTH APPLICATIONS

\section{CONCLUSION}

In this research, a study has been carried out to assess the usability of office application being installed on smart phones. During this research, various studies pertaining to the usability assessment factors and frameworks for mobile apps have been critiqued in an attempt to incur the usability that are well-matched with mobile office apps. After getting these factors, a collection of metrics (systems of measurement) has been designed for smart phones office apps in the form of Proposed Model.

The suggested model will facilitate users by enabling them to interact with more users' friendly office applications. The model suggested in this research has been validated by using User Centered methods like Usability testing, Think Aloud and Questionnaires. This model can be used for testing the office applications running on different mobile operating system.

\section{FUTURE WORK}

In future, suggested model can be used to evaluate usability of other business apps like OneNote, Outlook, Project and Visio by bringing forth some new systems of measurement depending upon the type of mobile application.

\section{ACKNOWLEDGEMENT}

Authors acknowledge Department of Computer Science, Lahore College for Women University, Lahore, Pakistan, for motivating and supporting us for the successful completion of this research work. Authors also acknowledge all the respondents for providing us their valuable suggestions and feedback in this research work.

\section{REFERENCES}

[1] Baharuddin, R., Singh, D., and Razali, R., "Usability Dimensions for Mobile Applications - A Review", Research Journal of Applied Sciences, Engineering and Technology, Volume 5, No. 6, pp. 2225-2231, 2013.

[2] Karapanos, E., "User Experience Over Time, In Modeling Users' Experiences with Interactive Systems", Chapter-4, Volume 436, pp. 57-83, Springer, Berlin, Heidelberg, 2013.

[3] Satistica, "Worldwide Consumer Spending on Mobile Apps in 2016, 2017 and 2021, by region (in Billion US\$)", 2018 [cited 201820 April]; Available from: https:// www.statista.com/statistics/695104/worldwide-mobileapp-consumer-spend-by-region/.

[4] Arena, G., "Mobile Phone Usage Report 2011. 2011" [cited 201820 April]; Available from: https:// www.gsmarena.com/mobile_phone_usage_surveyreview-592.php.

[5] Microsoft, "Microsoft Annual Report 2017", 2017 [cited 201820 April]; Available from: https:// www.microsoft.com/investor/reports/ar17/index.html.

[6] Moumane, K., and Idri, A., "Software Quality in Mobile Environments: A Comparative Study. In Control", Proceeding of 4th IEEE International Conference on Decision and Information Technologies, Barcelona, Spain, 2017.

[7] Guirguis, S.K., and Hassan, M.A., "A Smart Framework for Web Content and Resources Adaptation in Mobile Devices", Proceeding of $12^{\text {th }}$ IEEE International Conference on Advanced Communication Technology, Phoenix Park, South Korea, 2010.

[8] Hartmann, M., and Schreiber, D., "AUGUR: Interface Adaptation For Small Screen Devices, in Advances in Ubiquitous User Modelling", Lecture Notes in Computer Science, Volume 5830, pp. 94-110, Springer, Berlin, Heidelberg, 2009. 
[9] Seffah, A., Donyaee, M., Kline, R.B., and Padda, H.K., "Usability Measurement and Metrics: A Consolidated Model", Software Quality Journal, Volume 14, No 2, pp. 159-178, 2006

[10] Hussain, A., and Kutar, M., "Usability Metric Framework for Mobile Phone Application", Proceeding of 10th Annual Post-Graduate Symposium on The Convergence of Telecommunications, Networking and Broadcasting, Liverpool John Moores University, pp. 978-1, 2009.

[11] Ji, Y.G., Park,J.H., Lee, C., and Yun, M. H., “A Usability Checklist for The Usability Evaluation of Mobile Phone User Interface", International Journal of HumanComputer Interaction, Volume 20, No. 3, pp. 207-231, 2006 .

[12] Khan, M.A., Israr, N., and Hassan, S., "Usability Evaluation of Web Office Applications in Collaborative Writing in Intelligent Systems", Proceeding of $10^{\text {th }}$ IEEE International Conference on Modelling and Simulation, Liverpool, UK, 2010.

[13] Madan, A., and Dubey, S.K., "Usability Evaluation Methods: A Literature Review", International Journal of Engineering Science and Technology,Volume 4, No. 2, pp. 590-599, 2012

[14] Rodden, K., Hutchinson, H., and Fu, X., "Measuring the User Experience on a Large Scale: User-Centered Metrics For Web Applications", Proceedings of ACM Conference on Human Factors in Computing Systems, pp. 2395-2398, Atlanta, Georgia, USA, 2010.

[15] Khan, M., Sulaiman , S., Said, A.M., and Tahir, M., "Development of Usability Evaluation Framework for Haptic Systems", IEEE International Symposium on VR Innovation, Singapore, 2011.

[16] Hussain, A., and Kutar M., Apps Vs Devices: Can the Usability of Mobile Apps be Decoupled from the Device?", International Journal of Computer Science, Volume 9, No. 3, pp. 11-16, 2012.

[17] Rauf, A., Rehman, S.U., and Batool, S., "Survey Based Usability Evaluation of MS Word", Proceeding of IEEE International Conference on User Science and Engineering, Shah Alam, Selangor, Malaysia, 2010.

[18] Flood, D., Harrison, R., Iacob, Nosseir C., and McDaid, K., "Are Mobile Spreadsheet Applications Usable?", Journal of Organizational and End User Computing,Volume 25, No 1, pp. 43-63,2000.
[19] Gafni, R., "Usability Issues in Mobile-Wireless Information Systems", Issues in Informing Science \& Information Technology, Volume 6, pp. 755-769, 2009.

[20] Nielsen Holdings, N., "The Mobile Consumer: A Global Snapshot”, Nueva York, Estados, 2013.

[21] Zhang, D., and Adipat, B., "Challenges, Methodologies, and Issues in the Usability Testing of Mobile Applications", International Journal of HumanComputer Interaction, Volume 18, No. 3, pp. 293-308, 2005.

[22] Nawaz, M.S, Iqbal, Z., Lali, M.I., and Mustafa, R., "Mobile Application Testing in Pakistan: A Survey", Mehran University Research Journal of Engineering \& Technology, Volume 37, No. 1, pp 15-28, Jamshoro, Pakistan, January, 2018.

[23] Walji, M.F., Kalenderian, E.,Trana, D., Kookal, K.K., Nguyen, V., Tokede, O., White, J.M., Vaderhobli. R., Ramoni, R., Starke, P.C., Kimmes, S.N., SchoonheimKlein, M.E., and Patelh, V.L, "Detection and Characterization of Usability Problems in Structured Data Entry Interfaces in Dentistr", International Journal of Medical Informatics, Volume 82, No. 2, pp. 128-138, 2013.

[24] Hussain, A., Kutar, M., Mutalib, A.A., and Kamal, F.M., "Modeling Subjective Metrics for Mobile Evaluation", Journal of Research and Innovation in Information System, Volume 1, pp. 11-20, 2012.

[25] Giannopoulos, I., Kiefer, P., and Raubal, M., "The Influence of Gaze History Visualization on Map Interaction Sequences and Cognitive Maps", Proceedings of $1^{\text {st }}$ ACM International Workshop on MapInteraction, Orlando, Florida, 2013.

[26] Shivade, B., and Sharma, M., "Usability Analyzer Tool: A Usability Evaluation Tool for Android Based Mobile Application", International Journal of Emerging Trends \& Technology in Computer Science, Volume 3, No. 3, pp. 247-252, 2014.

[27] Faliagka, E., Rigou, M., and Sirmakessis, S., "A Usability Study of iphone Built-in Applications", Behaviour \& Information Technology, Volume 34, No. 8, pp. 799-808, 2015. 
[28] Hoehle, H., Aljafari, R., and Venkatesh, V., "Leveraging Microsoft $\times$ S Mobile Usability Guidelines: Conceptualizing and Developing Scales for Mobile Application Usability", International Journal of HumanComputer Studies, Volumn 89, pp. 35-53, 2016.

[29] Ventayen, R.J.M., Estira K.L.A., Guzman M.J.D., Cabaluna, C.M., and Espinosa, N.N., "Usability Evaluation of Google Classroom: Basis for the Adaptation of GSuite E-Learning Platform", Asia Pacific Journal of Education, Arts and Sciences, Volume 5, No. 1, pp. 47-51, 2018.

[30] Hussain, A., Mkpojiogu, E.O.C., Jamaludin, N.H., and Moh, S.T.L., "A Usability Evaluation of Lazada Mobile Application", Proceeding of $2^{\text {nd }}$ AIP International Conference on Applied Science and Technology, 2017.

[31] Nayebi, F., Desharnais, J.M., and Abran, A., "The State of the Art of Mobile Application Usability Evaluation", Proceeding of $25^{\text {th }}$ IEEE Canadian Conference on Electrical \& Computer Engineering, Montreal, QC, Canada , 2012.

[32] Venkatesh, V., Ramesh, V., and Massey, A.P., "Understanding Usability in Mobile Commerce", Communications of the ACM, Volumn 46, No. 12, pp 53-56, 2003.

[33] Guirguis, S.K., and Hassan, M.A., "A Smart Framework for Web Content and Resources Adaptation in Mobile Devices", Proceeding of $12^{\text {th }}$ IEEE International Conference on Advanced Communication Technology, pp. 1-6, 2010.

[34] Wogalter, M.S., and Cowley, J.A., "Usability Problems in Word Processing Applications", Proceedings of $17^{\text {th }}$ World Congress on Ergonomics, Beijin, China ,2009.

[35] Chintapalli, V.V., Tao,W., Meng, Z., Zhang, K., Kong, J., and Ge, Y., "A Comparative Study of Spreadsheet Applications on Mobile Device", Mobile Information Systems, pp. 1-10, 2016.

[36] Bota,H., Fourney, A., and Dumais, S.T.,"Characterizing Search Behavior in Productivity Software", Proceedings of $18^{\text {th }}$ Conference on Human Interaction and Reterival, New Brunswick, NJ, USA,2018.
[37] Attar, M.R., "Free Open-Source Software Has Gained The Popularity as A Software Development Method-A Review", International Journal of Advanced Research in Computer Science, Volume 8, No. 7, pp. 133-136, 2017.

[38] Castellucci, S.J., and MacKenzie, I.S., "Gathering Text Entry Metrics on Android Devices", Proceeding of $11^{\text {th }}$ ACM Conference on Extended Abstracts on Human Factors in Computing Systems, Vancouver, BC, Canada, 2011.

[39] Lobo, D., Kaskaloglu , K., Kim, C.Y., and Herbert, S., "Web Usability Guidelines for Smartphones: A Synergic Approach", International Journal of Information and Electronics Engineering, Volume 1, No. 1, pp. 33-37, 2011.

[40] Shackel, B., "Usability-Context, Framework, Definition, Design and Evaluation", Human Factors for Informatics Usability, Chapter-2, pp. 21-37, Cambridge University Press, 1991.

[41] Al-Radaideh, Q.A., Shanab, E.A., Hamam, S., and Salem, H.A., "Usability Evaluation of Online News Websites: A User Perspective Approach", International Journal of Human and Social Sciences, Volume 6, No. 2, pp. 114-122, 2011.

[42] Heo, J., Ham, D.H., Park, S., Song, C., and Yoon, W.C., "A Framework for Evaluating the Usability of Mobile Phones Based on Multi-Level, Hierarchical Model of Usability Factors", Interacting with Computers, Volume 21, No. 4, pp. 263-275, 2009.

[43] Tahir, R., and Arif, F., "A Measurement Model Based on Usability Metrics for Mobile Learning User Interface For Children", The International Journal of E-Learning and Educational Technologies in the Dgital Media, Volume 1, No. 1, pp. 16-31, 2015.

[44] Sommerville, I., and Dewsbury G., "Dependable Domestic Systems Design: A Socio-Technical Approach", Interacting with Computers, Volume 19, No. 7, pp. 438-456, 2007.

[45] Heo, J., Ham,D. H., Park, S., Song, C., and Yoon, W.C., "A Framework for Evaluating the Usability of Mobile Phones Based on Multi-Level, Hierarchical Model of Usability Factors", Interacting with Computers, Volume 21, No. 4, pp. 263-275, 2009. 